\title{
Rosa Bruno-Jofré and James Scott Johnston, eds. Teacher Education in a Transnational World
}

\author{
Toronto: University of Toronto Press, 2014. 466 pp.
}

\section{Lynn Lemisko}

University of Saskatchewan

Teaching is a complex process that relies on multi-layered knowledges, including understandings about how people learn; about social, emotional, and cultural identity factors that influence learning; about specific subject-area content; and the how-to knowledge of practice. Hence teaching how to teach is similarly complex to teaching itself, if not more so. Theories about best practices in teacher education have emerged over time, and research in teacher education has included examinations of ways in which local or national contexts have shaped teacher education programs. However, as the editors of this collection note in their introduction, there is an "... absence of a unified document bringing together analysis of programs, practices, and theories of teacher education with respect to what we are calling a 'globalizing and transnational world'" (3). Based on their concern that teacher education is under-theorized in relation to increasing pressures linked to globalization and transnationalization, editors Rosa Bruno-Jofré and James Scott Johnston have brought together distinguished contributors who examine issues connected to teacher education and higher education in this environment. In this collection, readers engage with eighteen chapters, a detailed introduction by the editors, and a reflective conclusion by Yvonne Hébert, a well-known scholar of citizenship, identity, and schooling.

Readers of HSE/RHE will be interested to learn that discussions of teacher education in the global context in this book are approached through historical, sociological, and philosophical perspectives. In an effort to create coherence among the eighteen chapters contributed by scholars from nine different countries, the editors have organized the essays into five sections, each with a particular focal point:

(1) Socio-political, Cultural, and Intellectual Spaces Where Teacher Education Is Located: A Historical, Sociological and Philosophical Approach; 
(2) Paradigmatic Changes in Teacher Education;

(3) Aboriginal Teacher Education in a Globalizing Context;

(4) The European Setting: Erasmus, Bologna, and the European Higher Education Area;

(5) Transnationalization and State Policies.

Furthermore, to generate coherence among the diverse discussions, the editors specifically identify in their introduction the chapters in which recurring themes in history, sociology, and philosophy can be explored by the reader. For example, BrunoJofré and Johnston point out that historical explanations are central to chapter 3, "To Serve and Yet Be Free: Historical Configurations and the Insertion of Faculties of Education in Ontario," and chapter 5, "From the Sacred Nation to the Unified Globe: Changing Leitmotifs in Teacher Training in the Western World, 1870-2010.” This reader also found, as the editors claimed, that a sense of history or "historical consciousness" (4) was evident in most of the chapters. After all, it seems difficult, if not impossible, to discuss, for example, the changes in German and Spanish teacher education programs following the Bologna Accord (chapter 13), without reference to the history of teacher education programs in these countries prior to its signing.

Other themes or strands identified by the editors and evident to this reader also provide coherence among the assembled essays. Philosophical questions, particularly those regarding epistemology and ontology, are taken up explicitly and implicitly in several chapters. There is a fascinating discussion offered by Johnston in chapter 2 . He argues in favour of pragmatism, rather than critical theory or post-structuralism, as a philosophical position from which to contemplate theories of teacher education as we face pressures arising in a globalized world. Chris Beeman, in an essay that explores the terms Aboriginal and Indigenous education, argues for deeply Indigenous ecological learning, which arises out of a way of living in relationship with place that "honours everyone's actual interdependence with the more-than-human" (200). In another example, the aim(s) of education in a globalized world are discussed in many chapters in this collection, with questions about these aims providing threads that can be followed across the five focal sections. To illustrate: economic/political aims related to human capital theories and development of competencies are important in Toporkoff's discussion of student and teacher mobility in Europe in chapter 12. In contrast, Jover and Geraldo's discussion in chapter 15 highlights cultural/philosophical aims related to the development of a "wisdom society" (310). In combination, these chapters provide readers with insights into competing and complementary aims that need to be contemplated by teacher educators developing programs in the transnational and globalized context.

The editors have made clear and deliberate efforts to highlight connections between the eighteen chapters in their introduction and they invited Hébert to write a summarizing conclusion that pulls together threads and themes in the book. These efforts aimed at creating a sense of unity in such a diverse edited collection 
are admirable. Even with these sections, however, this reader found a jarring exception to the overall coherence of the book. Although the authors make it clear that "this volume seeks to understand and locate teacher education in relation to international influences, international agreements, and national policies and processes of reception at the national and local level" (3-4), eight of the eighteen chapters do not directly address teacher education. Instead, these chapters discuss philosophical perspectives that could inform education in general (Noddings' chapter on cosmopolitanism); the theoretical and methodological issues that must be considered when embarking on comparative case study research involving diverse cultural contexts (Te Tuhi Robust's chapter on the importance of developing culturally appropriate Indigenous spaces within university settings); and issues related to tertiary education in general (Robinson's chapter on apprenticeship models for post-secondary learning, or Snowdon's chapter on the internationalization of higher education in Ontario). Based on the expectation that the book would focus on teacher education specifically, this reader looked forward to illuminating discussions about teacher education in a globalized world in every chapter and so was disappointed to find a lack of this specific focus in these eight chapters.

While it might be argued that theorizing teacher education in a globalized context can be informed by theorizing in higher education in general-because the former is a constituent of the latter - many essays in this collection make clear that coupling understandings about the evolution of higher education in a transnational world with the evolution of teacher education in this context is not necessarily helpful. For example, in the chapters that explore the Bologna Accord implementation processes with respect to teacher education in Germany and Spain (Valle, chapter 13) and Ukraine (Kutsyuruba, chapter 14), it is made clear that particular national contexts have a greater impact on the evolution of teacher education programming than does the accord. In this reader's estimation, this collection points to the conclusion that theorizing teacher education in a transnational world is a process that can be informed by perspectives from higher education, but that such theorizing must take into account the national particularities of teacher education.

Despite these issues, as a historian of education and a teacher educator, this reader found that each chapter contributes valuable insights into the complexities of educating in a globalizing and transnational world. The recurring themes in history, sociology, and philosophy across the chapters provide stimulating ideas that inform and intrigue. 